\title{
Paneer Whey as a Growth Medium for the Production of Antimicrobial Agents by Lactobacillus acidophilus - Optimization of Production Conditions
}

\author{
Shafna Zakkariya, Ligimol James", A.K. Beena and V. Aparna Sudhakaran \\ Department of Dairy Microbiology, College of Dairy Science and Technology, Kerala \\ Veterinary and Animal Sciences University, Mannuthy, Thrissur, Kerala, India \\ *Corresponding author
}

\begin{abstract}
A B S T R A C T
Whey, a by-product of cheese, paneer or casein production, is a high value byproduct of the dairy industry due to its nutritional composition and availability in large volumes.

Keywords

Antimicrobial activity, Lactobacillus

acidophilus, Heat stability, pH stability, Storage stability

Article Info

Accepted:

24 September 2018 Available Online:

10 October 2018

Owing to its high BOD (Biological oxygen demand) value and availability in surplus quantities, whey disposal is a serious problem from both an economical and an environmental point of view. Keeping these facts in view a study was conducted to assess the suitability of paneer whey as a growth medium of L. acidophilus for the production of inhibitory substances against $E$. coli, $S$. aureus, to optimize the production conditions and to partially characterize the antimicrobial agent present in the whey fermentate. On using sterilized paneer whey as the growth medium highest antimicrobial activity was obtained upon incubation at $37^{\circ} \mathrm{C}$ for 72 hours. Among the two indicator organisms used, higher activity was observed against the Gram positive organism Staphylococcus aureus than Escherichia coli, a Gram negative organism. On partially characterizing the antimicrobial agent/s it was found to be exocellular, highly heat resistant, optimally functional at a $\mathrm{pH}$ of 5 and stable under both room and refrigerated storage conditions. The successful use of paneer whey as a growth medium for production of antimicrobial agents is a promising step both from economic and environmental points of view.
\end{abstract}

\section{Introduction}

Whey, a liquid by-product obtained during manufacture of coagulated milk products like paneer, cheese etc. represents a rich and varied mixture of secreted proteins with wideranging physical, chemical and functional properties (Smithers et al., 1996). This very nutrient rich nature of whey also makes it a potent pollutant posing major disposal and pollution problems. So far no effective and permanent solution has been sorted out for this problem and different options are continuously being attempted in this direction. One of the options that has attracted much attention is the use of whey as a growth medium for the cultivation of Lactic acid bacteria (LAB); a group of Gram positive bacteria having a long history of safe use in the food industry. Among LAB, members of the genus Lactobacillus are widely used in food fermentations (Pyar and Peh, 2013) and 
among lactobacilli, Lactobacillus acidophilus is a species widely incorporated in dietary supplements with reported probiotic effects (Bull et al., 2013). It is a short $(2-10 \mu \mathrm{m})$ Gram-positive rod that grows optimally from $37^{\circ} \mathrm{C}$ to $42^{\circ} \mathrm{C}$ (Altermann et al., 2005) and is able to grow at temperatures as high as $45^{\circ} \mathrm{C}$. It is an obligate homofermenter producing lactic acid from fermentation of carbohydrates and is among the least oxygen tolerant lactobacilli (Archibald and Fridovich, 1981; Claesson et al., 2007). Among the different probiotic properties attributed to Lactobacillus acidophilus, its strong inhibitory effect against food borne pathogenic organisms is well acclaimed. This study is an attempt towards exploring the potential of paneer whey as a growth medium of a strain of Lactobacillus acidophilus for the production of antimicrobial agents against organisms Staphylococcus aureus and Escherichia coli.

\section{Materials and Methods}

\section{Microbial cultures}

The test organism used in the present study was Lactobacillus acidophilus -53(LA-53), initially isolated from household curd and maintained in the Lactic acid bacteria (LAB) culture collection of the Department of Dairy Microbiology, as a putative functional starter culture due to its high antimicrobial activity properties.

The indicator organisms used were Staphylococcus aureus and Escherichia coli. The Staphylococcus aureus culture was initially isolated from milk heat treated at $72^{\circ} \mathrm{C}$ for 3 minutes and was maintained as glycerol stock in the culture collection in the Department of Dairy Microbiology. The E coli used was an isolate obtained from pasteurised milk. All the cultures were maintained under refrigeration with fortnightly subculturing and whenever required active cultures were prepared by inoculation in sterilized medium and subsequent incubation.

Assessment of suitability of sterilized whey as a growth medium for the production of antimicrobial agents

Paneer whey collected from the dairy plant, Kerala veterinary and Animal Sciences University and sterilized by autoclaving was used as the growth medium. The sterilized paneer whey was stored overnight at room temperature to ensure its sterility and after that stored under refrigeration till its use. The suitability of sterilized whey as a growth medium for the production of antimicrobial agents by the test organism $L$ acidophilus 53 was determined by the well diffusion method. For this overnight incubated culture of $L$ acidophilus (approximate count $-10^{3} \mathrm{CFU} / \mathrm{ml}$ ) was inoculated at 2 per cent rate into sterilized paneer whey and incubated at $37^{\circ} \mathrm{C}$ for 48 hours. After the incubation, $100 \mu 1$ of fermented paneer whey was introduced into the already prepared wells $(6 \mathrm{~mm}$ diameter wells punched out with a sterile well borer) in the Mueller Hinton Agar Petriplates swabbed with indicator organisms, Escherichia coli and Staphylococcus aureus adjusted to an optical density of 0.3 (approximate count- $2.5 \times 10^{2}$ $\mathrm{CFU} / \mathrm{ml}$ ) at $540 \mathrm{~nm}$. In one of the wells unfermented sterilized paneer whey was loaded to serve as a control. The plates were incubated at $37^{\circ} \mathrm{C}$ for 24 hours and observed for the development of zone of clearance around the wells indicating the production antimicrobial agents by the test organism.

For determining the nature of antimicrobial agents as either exogenous or endogenous, the antimicrobial activity of the culture free whey fermentate (CFWF) prepared by centrifuging the fermented whey at $10,000 \mathrm{rpm}$ for 5 minutes was compared with that of whey fermentate by the well diffusion method adopting the procedure mentioned above. 
Optimization of production of antimicrobial agents in terms of period and temperature of incubation

Optimum temperature of incubation was determined by incubating the sterilized whey inoculated with the L. acidophilus 53 at 2 per cent rate at different temperatures $\left[37^{\circ} \mathrm{C}\right.$, $42^{\circ} \mathrm{C}$, room temperature and refrigeration temperature $\left.\left(4^{0} \mathrm{C}\right)\right]$ for 24 hours and observing for the antagonistic activity against the indicator organisms by the well diffusion method. The optimum period of incubation was determined in a similar way up to a period of 240 (10 days) hours with sampling for antagonistic activity at every $24 \mathrm{~h}$ interval.

Partial characterization of antimicrobial agents produced by the test organismHeat, $\mathrm{pH}$ and Storage stabilities

To check the heat stability, samples of cell free whey fermentate were transferred to sterile tubes and subjected to a heat treatment of 15 minutes at $60^{\circ} \mathrm{C}, 90^{\circ} \mathrm{C}, 120^{\circ} \mathrm{C}$ and $160^{\circ} \mathrm{C}$ and tested for antimicrobial activity by the well diffusion assay. The $\mathrm{pH}$ stability was assessed by testing the antimicrobial activity of the $\mathrm{pH}$ adjusted samples ( 3 to 11 by the drop by drop addition of either Hydrochloric acid or Sodium Hydroxide) of cell free whey ferment ate by the well diffusion method. Samples of cell free whey ferment ate were also assessed for the storage stability of its antimicrobial activity at refrigerated and room temperature by the well diffusion method at 3 days interval for a period of 10 days.

\section{Results and Discussion}

Assessment of suitability of sterilized paneer whey as a growth medium for the production of antimicrobial agents

Well diffusion assay of the paneer whey fermentate of L. acidophilus LA-53 resulted in zones of clearance around the wells indicating the suitability of whey as a growth medium for the production of antimicrobial agents against $S$ aureus, a Gram positive organism and $E$ coli, a Gram negative organism (Table 1). Antimicrobial activity of Lactobacillus whey fermentate against a number of antibiotic resistant pathogenic strains of $E$. coli, $B$. cereus, S. typhi, E. faecalis, L. monocytogens, $S$. aureus and Pseudomonas species was reported by Borkar (2011). In agreement with this, in the present study also antagonistic activity against $S$ aureus and $E$ coli was exhibited by the whey fermentate. Inhibitory effect of bioactive peptides derived from whey based Lactobacillus acidophilus fermented probiotic beverage against a number of Gram positive (E. faecalis, B. cereus, Listeria monocytogenes and $S$. aureus) and Gram negative (E. coli, S. typhi, and Sh. dysenteriae) organisms was reported by Kumari and Vij (2015). Among the two indicator organisms used, higher activity was exhibited against the Gram positive organism Staphylococcus aureus than Escherichia coli, a Gram negative organism. The greater antagonistic activity observed against the Gram positive microorganism than the Gram negative microorganism is in accordance with previous reports (Kivancet al., 2011, Georgieva et al., 2015, Kumari and Vij, 2015). Antibacterial activity against Gram-positive pathogens is mostly attributed to the bactericidal effect of protease sensitive bacteriocins, (Atanassova $e t$ al., 2003, De Vuyst and Leroy, 2007) while that towards Gram-negative pathogens is ascribed to the production of organic acids and hydrogen peroxide (Makras and De Vuyst, 2006; Makras et al., 2006). In this context, the higher inhibitory effect of whey fermentate towards the Gram positive bacteria $S$. aureus than the Gram negative bacterium E. coli could be due to the production of bateriocins, which needs to be further investigated. Though both the target organisms were adjusted to the same optical density prior to 
spreading $(0.3$ at $540 \mathrm{~nm})$, due to the higher growth rate of $E$. coli compared to $S$. aureus, the former always exhibited a better lawn like growth on Mueller Hinton plates.

Both the cell containing and cell free whey fermentates (CCWF, CFWF) of $L$. acidophilus-53 showed antibacterial activity against the tested target organisms (Table 2) and as no marked difference was observed between the two, the exocellular release of antimicrobial agents was presumed and it was decided to use CFWF for subsequent studies.

Optimization of production of antimicrobial agents in terms of period and temperature of incubation

Irrespective of the sample used and indicator organism tested, largest zones of inhibition were observed after $72 \mathrm{~h}$ of incubation (Table 2). Maximum antimicrobial activity in whey fermentate concentrate after $24-48 \mathrm{~h}$ of incubation and decrease after $48 \mathrm{~h}$ was reported by Borkar (2011). In the current study gradual reduction in antimicrobial activity against both the indicator organisms was observed on incubation beyond $72 \mathrm{~h}$. Though a very drastic reduction was observed in the antimicrobial activity against $E$ coli after $216 \mathrm{~h}$, no such trend was observed in the case of $S$. aureus.

Temperature dependent variation was observed in the production of antimicrobial agents by LA-53 with incubation at room temperature and $37^{\circ} \mathrm{C}$ resulting in the largest zone of inhibition (Table 3). No zone of inhibition was observed on incubation at $42^{\circ} \mathrm{C}$ and under refrigeration $\left(4^{0} \mathrm{C}\right)$.

So $37^{0} \mathrm{C}$ was selected as the optimum temperature of incubation for the production of antimicrobial agents by LA-53 (Fig. 1).

Table.1 Antimicrobial activity of paneer whey fermented with L acidophilus LA-53

\begin{tabular}{|c|c|c|}
\hline \multirow{2}{*}{ Sample } & Zone of inhibition (mm, inclusive of well diameter) \\
\hline Whey fermentate & Staphylococcus aureus & Escherichia coli \\
\hline Sterilized whey & 20 & 13 \\
\hline
\end{tabular}

Table.2 Nature of the antimicrobial agents and effect of period of incubation on production of antimicrobial agents

\begin{tabular}{|c|c|c|c|c|c|c|c|c|c|c|c|c|}
\hline \multirow{2}{*}{$\begin{array}{l}\text { S. } \\
\text { No. }\end{array}$} & \multirow{2}{*}{$\begin{array}{l}\text { Indicator } \\
\text { organism }\end{array}$} & \multirow[t]{2}{*}{ Sample } & \multicolumn{10}{|c|}{ Zone Of Inhibition (mm, inclusive of well diameter)) } \\
\hline & & & $\begin{array}{c}24 \\
\text { h }\end{array}$ & $\begin{array}{l}48 \\
h\end{array}$ & $\begin{array}{c}72 \\
\text { h }\end{array}$ & $\begin{array}{c}96 \\
\mathrm{~h}\end{array}$ & $\begin{array}{c}120 \\
\text { H }\end{array}$ & $\begin{array}{c}144 \\
\text { h }\end{array}$ & $\begin{array}{c}168 \\
h\end{array}$ & $\begin{array}{c}192 \\
\text { h }\end{array}$ & $\begin{array}{c}216 \\
h\end{array}$ & $\begin{array}{c}240 \\
h\end{array}$ \\
\hline \multirow[t]{2}{*}{1} & \multirow[t]{2}{*}{$S$ aureus } & CCWF & $\begin{array}{r}14.5 \\
\pm 0.7\end{array}$ & $\begin{array}{l}20 \\
\pm 0\end{array}$ & $\begin{array}{r}24.5 \\
\pm 0.7\end{array}$ & $\begin{array}{l}23.5 \\
\pm 0.7\end{array}$ & $\begin{array}{r}22.5 \\
\pm 0.7\end{array}$ & $\begin{array}{l}21 \\
\pm 0\end{array}$ & $\begin{array}{r}20 \\
\pm 0\end{array}$ & $\begin{array}{r}19 \\
\pm 0\end{array}$ & $\begin{array}{r}18 \\
\pm 0\end{array}$ & $\begin{array}{l}14.5 \\
\pm 0\end{array}$ \\
\hline & & CFWF & $\begin{array}{r}12.5 \\
\pm 0.7\end{array}$ & $\begin{array}{c}19 \\
\pm 1.4\end{array}$ & $\begin{array}{c}24 \\
\pm 1.4\end{array}$ & $\begin{array}{c}23 \\
\pm 1.4\end{array}$ & $\begin{array}{r}21.5 \\
\pm 0.7\end{array}$ & $\begin{array}{l}21 \\
\pm 0\end{array}$ & $\begin{array}{l}20 \\
\pm 0\end{array}$ & $\begin{array}{c}18 \\
\pm 0\end{array}$ & $\begin{array}{c}17 \\
\pm 0\end{array}$ & $\begin{array}{r}14.5 \\
\pm 0.7\end{array}$ \\
\hline \multirow[t]{2}{*}{2.} & \multirow[t]{2}{*}{ E coli } & CCWF & $\begin{array}{c}11 \\
\pm 0\end{array}$ & $\begin{array}{r}12.5 \\
\pm 0.7\end{array}$ & $\begin{array}{c}15 \\
\pm 0\end{array}$ & $\begin{array}{c}14 \\
\pm 0\end{array}$ & $\begin{array}{c}13 \\
\pm 0\end{array}$ & $\begin{array}{c}12 \\
\pm 0\end{array}$ & $\begin{array}{c}12 \\
\pm 0\end{array}$ & $\begin{array}{c}11 \\
\pm 0\end{array}$ & 0 & 0 \\
\hline & & CFWF & $\begin{array}{c}11 \\
\pm 0\end{array}$ & $\begin{array}{c}12 \\
\pm 0\end{array}$ & $\begin{array}{r}14.5 \\
\pm 0.7\end{array}$ & $\begin{array}{r}13.5 \\
\pm 0.7\end{array}$ & $\begin{array}{r}12.5 \\
\pm 0.7\end{array}$ & $\begin{array}{c}12 \\
\pm 0\end{array}$ & $\begin{array}{c}12 \\
\pm 0\end{array}$ & $\begin{array}{c}11 \\
\pm 0\end{array}$ & 0 & 0 \\
\hline
\end{tabular}

Data are presented as Mean $\pm \mathrm{SD}(\mathrm{n}=2)$ 
Table.3 Effect of temperature of incubation on antimicrobial activity

\begin{tabular}{|c|c|c|c|}
\hline S. No. & & $\begin{array}{l}\text { Zone of inhibition ( } \\
\text { diameter) }\end{array}$ & inclusive of we \\
\hline & Temperature of incubation & Staphylococcus aureus & Escherichia coli \\
\hline 1. & $37^{0} \mathrm{C}$ & 25 & 15 \\
\hline 2. & Room & 24 & 14 \\
\hline 3. & $42^{0} \mathrm{C}$ & 0 & 0 \\
\hline 4. & Refrigeration & 0 & 0 \\
\hline
\end{tabular}

Table. $4 \mathrm{pH}$ stability of antimicrobial agents produced by LA-53

\begin{tabular}{|c|c|c|c|}
\hline S. No. & pH of CFWF & \multicolumn{2}{|c|}{ Zone of inhibition (mm, inclusive of well diameter) } \\
\hline & & Staphylococcus aureus & Escherichia coli \\
\hline 1. & 3 & 0 & 0 \\
\hline 2. & 5 & 23 & 15 \\
\hline 3. & 7 & 20 & 12 \\
\hline 4. & 9 & 0 & 0 \\
\hline 5. & 11 & 0 & 0 \\
\hline
\end{tabular}

Table.5 Storage Stability of antimicrobial agents produced by LA-53

\begin{tabular}{|c|c|c|c|c|c|c|c|c|c|}
\hline \multirow[t]{3}{*}{ S. No. } & \multirow{3}{*}{$\begin{array}{c}\text { Target } \\
\text { organism }\end{array}$} & \multicolumn{8}{|c|}{ Zone of Inhibition (mm) (\% Retention of antimicrobial activity) } \\
\hline & & \multicolumn{4}{|c|}{ Room temperature } & \multicolumn{4}{|c|}{ Refrigeration } \\
\hline & & $\begin{array}{c}24 \\
\mathrm{~h}\end{array}$ & $\begin{array}{c}96 \\
h\end{array}$ & $\begin{array}{c}168 \\
\mathrm{~h}\end{array}$ & $\begin{array}{c}240 \\
\mathrm{~h}\end{array}$ & $\begin{array}{c}24 \\
h\end{array}$ & $\begin{array}{c}96 \\
h\end{array}$ & $\begin{array}{c}168 \\
\mathrm{~h}\end{array}$ & $\begin{array}{c}240 \\
\mathrm{~h}\end{array}$ \\
\hline 1. & S. aureus & $\begin{array}{c}24 \\
(100)\end{array}$ & $\begin{array}{c}21 \\
(87.5)\end{array}$ & $\begin{array}{c}18 \\
(75)\end{array}$ & $\begin{array}{c}15 \\
(62.5)\end{array}$ & $\begin{array}{c}24 \\
(100)\end{array}$ & $\begin{array}{c}23 \\
(96)\end{array}$ & $\begin{array}{c}21 \\
(87.5)\end{array}$ & $\begin{array}{c}19 \\
(79)\end{array}$ \\
\hline 2. & E. coli & $\begin{array}{c}15 \\
(100)\end{array}$ & $\begin{array}{c}13 \\
(87)\end{array}$ & $\begin{array}{c}11 \\
(73)\end{array}$ & $\begin{array}{c}0 \\
(0)\end{array}$ & $\begin{array}{c}15 \\
(100)\end{array}$ & $\begin{array}{c}14 \\
(93)\end{array}$ & $\begin{array}{c}13 \\
(87)\end{array}$ & $\begin{array}{c}11 \\
(73)\end{array}$ \\
\hline
\end{tabular}


Fig.1 Effect of period of incubation on production of antimicrobial agents: Mueller Hinton agar plates showing zones of clearance



Fig.2 Antimicrobial activity of CFWF subjected to different heat treatments

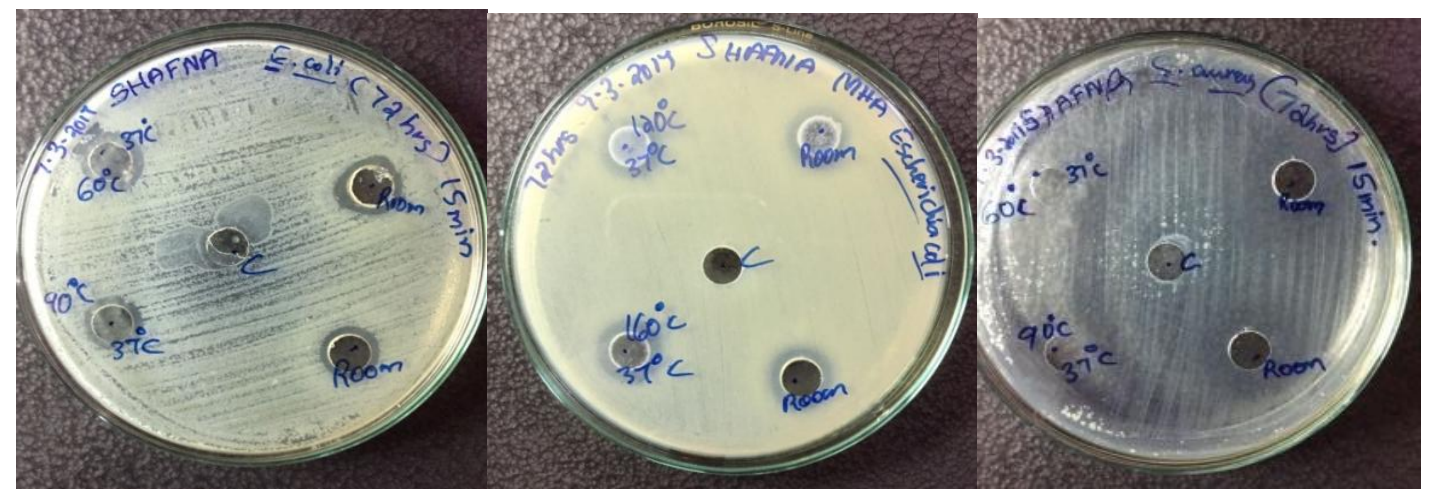

Fig. 3 Heat stability of antimicrobial agents produced by LA-53

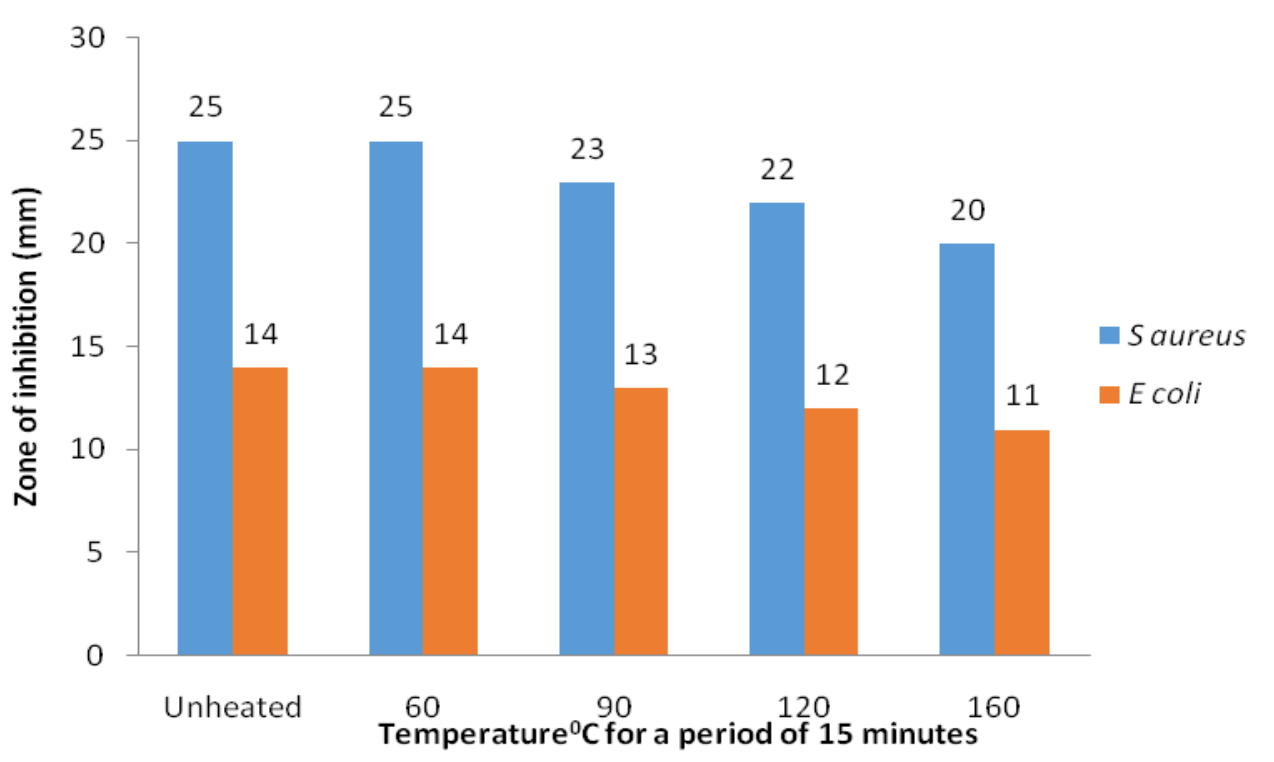


Fig.4 Antimicrobial activity of CFWF adjusted to different $\mathrm{pH}$ levels



A. Escherichia coli

Partial characterization of antimicrobial agents produced by the test organismHeat, $\mathrm{pH}$ and Storage stabilities

It is clear from the data presented in Fig. 2 and 3 that the antimicrobial agents produced by LA-53 were highly heat resistant. No decrease in the antimicrobial activity was observed even after heating at $60^{\circ} \mathrm{C}$ for 15 minutes. Though there was a gradual reduction in the diameter of zones of clearance proportionate to increase in temperature, almost $79-80 \%$ of its activity was retained even after a heat treatment of $160^{\circ} \mathrm{C}$ for 15 minutes. Such high heat stability of antimicrobial agents of lactic acid bacteria are reported by other researchers also. Retention of the antimicrobial activity of supernatant of L. acidophilus strain LA-53 even after a heat treatment of $110^{\circ} \mathrm{C}$ for $1 \mathrm{~h}$ was reported by Coconnier et al., (1997). Antagonistic activity of supernatant of $L$. casei GC subgroup A heated at $100^{\circ} \mathrm{C}$ for 10 min against reference strains $L$. acidophilus, $L$. fermentum and $L$. plantarum was reported by Oh et al., (2000). Ollveira et al., (2008) observed that the antimicrobial compound produced by $L$. acidophilus $30 \mathrm{SC}$ was heat stable at $95^{\circ} \mathrm{C}$ for $20 \mathrm{~min}$ and $50 \%$ of activity was lost after heating at $121^{\circ} \mathrm{C}$ for $20 \mathrm{~min}$. Heat stability of cell free supernatants of six $L$

\section{B. Staphylococcus aureus}

acidophilus strains at 90 and $121^{\circ} \mathrm{C}$ for $1 \mathrm{~h}$ and enhancement in the antibacterial effect after heat treatments was reported by Aween et al., (2012).

Antagonistic activity was exhibited by the CFWF only in the $\mathrm{pH}$ range of 5-7 and adjustment of $\mathrm{pH}$ from its normal $\mathrm{pH}$ of 5 to 3 resulted in complete loss of its antimicrobial activity (Table 4 and Fig. 4). Same thing was observed on adjusting the $\mathrm{pH}$ to the alkaline side of 9 and 11. Irrespective of the target organism, the cell free whey fermentate exhibited highest antimicrobial activity at its innate $\mathrm{pH}$ of 5 . Though there was a reduction the inhibitory effect was present even at $\mathrm{pH} 7$ suggesting the presence of some antagonistic factor other than the acidic metabolites produced by the test organism. The results also indicate that the antibacterial activity was effective only in the $\mathrm{pH}$ range of 5-7.

On assessing the storage stability of antimicrobial effect of CFWF at room and refrigerated temperature it was found that the antimicrobial effect was evident even after 10 days $(240 \mathrm{~h})$ of storage under both conditions (Table 5). $79 \%$ of the antagonistic activity against $S$. aureus was retained upon 10 days of refrigerated storage whereas on room 
temperature storage, it was only $62.5 \%$. Against $E$ coli, the activity was completely lost after 10 days of storage at room temperature but $73 \%$ was retained upon refrigerated storage. The differential nature of the antagonistic effect between $E$. coli and $S$. aureus on storage also substantiate the presumption that either different inhibitory factors might be acting or there might be difference in the nature of activity of agents depending on whether the organism is Gram positive or Gram negative.

To summarize, results of study demonstrates that paneer whey could be used as an effective growth media for the cultivation of Lactobacillus acidophilus -53(LA-53) for the production of antimicrobial agents against $S$. aureus and E. coli. The successful use of paneer whey as a growth medium is highly advantageous from the economic as well as environment friendly byproduct utilization point of view and needs to be further explored.

\section{References}

Altermann, E., Russell, W.M. and AzcaratePeril, 2005. Complete genome sequence of the probiotic lactic acid bacterium Lactobacillus acidophilus NCFM.P Natl. Acad. Sci.USA102: 3906-3912.

Archibald, F.S. and Fridovich I., 1981. Manganese, superoxide dismutase, and oxygen tolerance in some lactic acid bacteria. J. Bacteriol. 146(3): 928-936.

Atanassova, M., Choiset, Y., Dalgalarrondo, M., Chobert. J.M., Dousset, X., Ivanova, I. and Haertle, T., 2003. Isolation and partial bio-chemical characterization of a proteinaceous antibacteria and anti-yeast compound produced by Lactobacillu spara-casei subsp. paracasei strain M3. Int. J. Food Microbiol. 87(1-2): 63 -73.
Aween, M. M., Zaiton, H., Belal J., Noor, H.M. and Eljamel, Y.A., 2012. Evaluation on Antibacterial Activity of Lactobacillus acidophilus Strains Isolated from Honey. Am. J. Appl. Sci. 9: 807-817.

Borkar, S. P., 2011. Antimicrobial activity of whey and sodium caseinate fermentate of lactobacillus cultures against antibiotic resistant pathogens, M.Tech. Thesis submitted to NDRI, krishikosh.egranth.ac.in/.../1/.../Shital_F inal_Thesis.pd.

Bull M., Plumme, S., Marchesi, J. and Mahenthiralingam E., 2013. The life history of Lactobacillus acidophilus as a probiotic: a tale of revisionary taxonomy, misidentification and commercial success. FEMS Microbiol Lett. 349(2): 77-87.

Claesson, M.J., van Sinderen D. and O'Toole P.W. 2007. The genus Lactobacillus-a genomic basis for understanding its diversity. FEMS Microbiol. Lett. 269(1): 22-28.

Coconnier M.H, Lievin V, Bernet-Camard M.F, Hudault S and Servin A.L., 1997. Antibacterial effect of the adhering human Lactobacillus acidophilus strain LB. Antimicrob. Agents Chemother. 41 (5): 1046-1052.

De Vuyst L. and Leroy F. 2007. Bacteriocins from lactic acid bacteria: production, purification, and food applications. J. Microbiol. Biotechnol. 13(4): 194 -199.

Kivanc M, Yilmaz M and Cakir E.2011. Isolation and identification of lactic acid bacteria from boza, and their microbial activity against several reporter strains. Turk. J. Biol. 35(3):313-324.

Kumari S and Vij S., 2015. Effect of bioactive peptides derived from fermented whey based drink against food borne pathogens. Int. J. Microbi. 4(3): 936 941. 
Makras L, Triantafyllou V, Fayol-Messaoudi D, Adriany T, Zoumpopoulou G, Tsakalidou E, Servin A and De Vuyst L., 2006. Kinetic analysis of the antibacterial activity of probiotic lactobacilli towards Salmonella enteric serovar typhimurium reveals a role for lactic acid and other inhibitory compounds. Res. J. Microbiol. 157(3): 241- 247.

Maurad K and K.H. Meriem., 2008. Probiotic characteristics of Lactobacillus plantarum strains from traditional butter made from camel milk in arid regions (Sahara) of Algeria: Grasas Y Aceites, 59 (3): 218-224.

Oh, S., Kim S.H. and Worobo R.W., 2000. Characterization and purification of a bacteriocin produced by a potential probiotic culture, Lactobacillus acidophilus 30SC. J. Dairy Sci. 83 (12): 2747-2752.

Ollveira R.B.P., Ollveira A.D.L. and Glória M.B.A., 2007. Screening of lactic acid bacteria from vacuum packaged beef for antimicrobial activity. Braz. J. Microbiol. 39(2): 368-374.

Pyar H. and Peh K.K., 2013. Characterisation and Identification of Lactobacillus acidophilus using Biology Rapid Identification System. Int. J. Pharm. Pharm. Sci. 6 (1): 189-193.

Smithers, G. W., Ballard, F. J., Copeland, A. D., De Silva, K. J., Dionysius, D. A., Francis, G. L., Goddard, C., Grieve, P. A., McIntosh, G. H., Mitchell, I. R., Pearce, R. J. and Regester, G. O. 1996. New opportunities from the isolation and utilization of whey proteins. J. Dairy Sci., 79 (8): 1454-1459

\section{How to cite this article:}

Shafna Zakkariya, Ligimol James, A.K. Beena and Aparna Sudhakaran, V. 2018. Paneer Whey as a Growth Medium for the Production of Antimicrobial Agents by Lactobacillus acidophilus - Optimization of Production Conditions. Int.J.Curr.Microbiol.App.Sci. 7(10): 3165-3173. doi: https://doi.org/10.20546/ijcmas.2018.710.367 